\title{
GROUND ACCELERATIONS CAUSED BY LARGE QUARRY BLASTS
}

\author{
By D. E. Hudson, J. L. Alford, and W. D. Itan
}

\begin{abstract}
Ground acceleration-time measurements have been made within $2000 \mathrm{ft}$. of two quarry blasts of total charge weight 185 tons and 673 tons. Ground accelerations were of a character and magnitude similar to those associated with damaging earthquakes. Complete response spectrum curves calculated from the acceleration records are presented. Direct comparisons are made between these results and previous similar measurements and calculations using identical instruments, which have been made of strong-motion earthquakes, H. E. blasts, and the Rainier nuclear blast.
\end{abstract}

\section{INTRODUCTION}

Ground accelerations caused by quarry blasts may be influenced by many factors such as distance, charge weight, local geological structure, and soil conditions. It has thus been difficult to compare acceleration measurements made at various sites, particularly in view of the fact that a wide variety of instruments having quite different response characteristics have been used for such studies.

The quarry blast reported in the present paper involved a total charge weight of $1,347,000 \mathrm{lb}$. of high explosive. Through the cooperation of the United States Coast and Geodetic Survey it was possible to measure the ground acceleration with the same type of strong-motion earthquake accelerographs that had been used for various strong-motion earthquake recordings and for measurements of previous $\mathrm{H}$. $\mathrm{E}$. blasts as well as the Rainier nuclear blast. The measured ground accelerations were of an order of magnitude directly comparable to those of destructive earthquakes, and hence some correlations between the structural effects of earthquakes and blasts can be established.

\section{The February 18, 1958 Corona Blast}

The Corona Quarry of the Minnesota Mining and Manufacturing Company is located about 5 miles from the town of Corona, California. The rock material at this site is a fairly solid, moderately fissured, friable dacite porphyry. Mill buildings for rock-crushing operations, and various processing and office buildings are located some $190 \mathrm{ft}$. below the level of the blast face on various thicknesses of downwash from the surrounding hills.

The general layout of the test site is shown in fig. 1. In an attempt to determine the details of the local structure in the vicinity of the measuring points, three test borings were made as indicated in fig. 1, with the following results:

Hole No. 1. Surface to $20 \mathrm{ft}$. Mixed fill of silty sand and angular rock. $1{ }^{\prime \prime}-15^{\prime \prime}$ diameter, 20 $23 \mathrm{ft}$. Sand with $30 \%$ rock, $\frac{11}{4}-3^{\prime \prime} ; 23-26 \mathrm{ft}$. silt; $26-28 \mathrm{ft}$. Sand with $30 \%$ rock, $\frac{1}{4}{ }^{\prime \prime}-6^{\prime \prime}$. Some of rock is waterworn river gravel; $28-34$, silty clay with $50 \%$ rock and gravel; $34-36$, sand with $30 \%$ rock and gravel; $36-39$, silt with some rock; $39-43$, sand with $50 \%$ rock $\frac{11}{4}-15^{\prime \prime}$; end of hole, heavy boulders.

Hole No. 2. Elevation of top of hole $35 \mathrm{ft}$. above top of Hole No. 1. Surface to $22 \mathrm{ft}$., sandy silt and silty sand with $20 \%-40 \%$ sharp angular rock, $\frac{11}{4}-24^{\prime \prime}$ diameter. $22-23 \mathrm{ft}$., in place dacite porphyry or a very large boulder.

Manuscript received for publication September 1, 1960. 
Hole No. 3. Elevation of top of hole, $7 \frac{1}{2} \mathrm{ft}$. below top of Hole No. 1. Surface to $16 \mathrm{ft}$., silty sand with $\frac{11}{4}-36^{\prime \prime}$ diameter rock. Sharp, angular rock, outwash from hills; $16-20 \mathrm{ft}$., sand with $25 \%-35 \%$ rock, $\frac{11}{1}-9^{\prime \prime}$; end of hole at $20 \mathrm{ft}$. at rock in place or a very large boulder.

It was not possible with the above borings to establish with certainty the location of the in-place rock, although the major features of the soil conditions at the measuring points were determined.

The explosive charge was composed of $924,000 \mathrm{lb}$. of nitramite, $420,000 \mathrm{lb}$. nilite, and $3,000 \mathrm{lb}$. of primer. The total charge was distributed in a tunnel system as shown in fig. 1, and was sub-divided into three charges of 60 tons, 237 tons, and 376 tons, fired at time delays of 17 milliseconds.

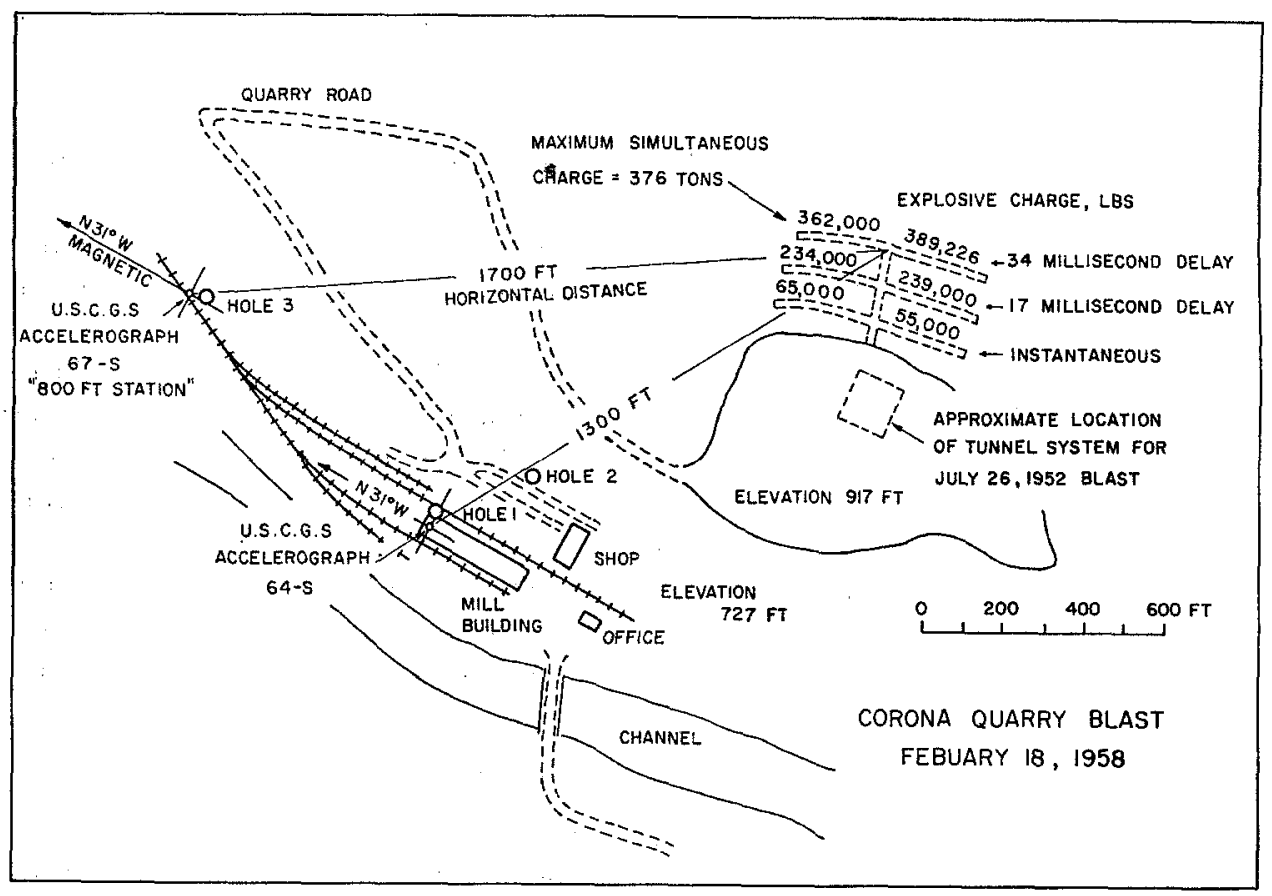

Fig. 1. General Plan of Test Site and Instrument Locations.

\section{Ground Accemeration Instrumentation}

Ground accelerations during the blast were measured with standard United States Coast and Geodetic Survey Strong-Motion Earthquake Accelerographs. The characteristics of these instruments are given in Table I. At the periods and damping used, the records should accurately represent the true ground acceleration for periods above $0.1 \mathrm{sec}$.

The accelerograph at the Mill Building station was located on the concrete subbasement floor of the building, about $15 \mathrm{ft}$. below the ground surface. The accelerograph at the $800 \mathrm{ft}$. station was located on soil as described above at Hole No. 3, in a shallow railroad track cut. 


\section{Ground Acceleration Records}

In fig. 2 are shown the ground acceleration-time records for each of the two stations drawn to the same scale. On the same figure are shown for comparison the three components of ground acceleration recorded at the Mill Building Station during the quarry blast of July 26, 1952. ${ }^{1}$ This 1952 blast was a simultaneously fired charge of 185 tons of explosive in practically the same location as the 1958 shot, as indicated in fig. 1. Also shown in fig. 2 is a reproduction of one of the original accelerograph records.

TABLE I

Characteristics of U.S.C.G.S. AcCelerographs

\begin{tabular}{|c|c|c|c|c|c|c|}
\hline & \multicolumn{3}{|c|}{$\begin{array}{l}\text { Accelerograph No. 64-S "Mill Building } \\
\text { Station" }\end{array}$} & \multicolumn{3}{|c|}{ Accelerograph No. 67-S " 800 Ft. } \\
\hline & $\begin{array}{c}\text { Vertical } \\
\text { accel. } \\
\text { no. } 1013\end{array}$ & $\begin{array}{c}\mathrm{N} 31^{\circ} \mathrm{W} \\
\text { accel. } \\
\text { no. } 1014\end{array}$ & $\begin{array}{c}\mathrm{N} 59^{\circ} \mathrm{E} \\
\text { accel. } \\
\text { no. } 1015\end{array}$ & $\begin{array}{l}\text { Vertical } \\
\text { accel. } \\
\text { no. } 1016\end{array}$ & $\begin{array}{c}\mathrm{N} 31^{\circ} \mathrm{W} \\
\text { accel. } \\
\text { no. } 1017\end{array}$ & $\begin{array}{c}\mathrm{N} 59^{\circ} \mathrm{E} \\
\text { accel. } \\
\text { no. } 1018\end{array}$ \\
\hline Period, seconds & 0.0813 & 0.0854 & 0.0846 & 0.0836 & 0.0849 & 0.0841 \\
\hline $\begin{array}{l}\text { Damping, fractional criti- } \\
\text { cal }\end{array}$ & 0.61 & 0.62 & 0.65 & 0.59 & 0.57 & 0.53 \\
\hline Sensitivity, $\mathrm{mm} / 0.1 \mathrm{~g}$ & 19.5 & 21.7 & 20.9 & 19.9 & 20.9 & 21.4 \\
\hline
\end{tabular}

Paper Speed, $35 \mathrm{~mm} / \mathrm{sec}$.

\section{Spectrum Analysis of Ground Acceleration Records}

As a means of studying the frequency characteristics of the ground acceleration records, and of indicating the effect of such ground accelerations on structures, the response spectrum curves were calculated. ${ }^{2}$ These calculations were made using the Electric Analog Type Response Spectrum Analyzer which had been developed for the analysis of strong-motion earthquake records, and these response spectrum curves can be directly compared with similar velocity spectrum curves obtained for earthquakes. ${ }^{3}$ The resulting spectrum curves are shown in figs. 3-6, and in figs. 7, 8 are shown corresponding curves for the 1952 blast, which have not been published in a complete form before.

It will be noted that the spectrum curves are similar in many respects to those obtained from a short duration earthquake. ${ }^{4,5}$ Blasts usually exhibit a simpler

1 Hudson, D. E., J. L. Alford, and G. W. Housner, "Measured Response of a Structure to an Explosive-Generated Ground Shock," Bull. Seis. Soc. Amer., vol. 44, No. 3, July 1954.

${ }^{2}$ Hudson, D. E., "Response Spectrum Techniques in Engineering Seismology," Proc. World Conference on Earthquake Engineering, Earthquake Engineering Research Institute and University of California, Berkeley, 1956.

${ }^{3}$ Housner, G. W., R. R. Martel, and J. L. Alford, "Spectrum Analysis of Strong-Motion Earthquakes," Bull. Seis. Soc. Amer., vol. 43, No. 2, April 1953.

${ }^{4}$ Housner, G. W., and D. E. Hudson, "The Port Hueneme Earthquake of March 18, 1957," Bull. Seis. Soc. Amer., vol. 48, No. 2, April 1958.

5 Hudson, D. E., and G. W. Housner, "Response Spectrum Analysis of the San Francisco Earthquake of March 22, 1957,"San Francisco Earthquakes of March, 1957, Special Report 57, California Division of Mines, San Francisco, 1959. 

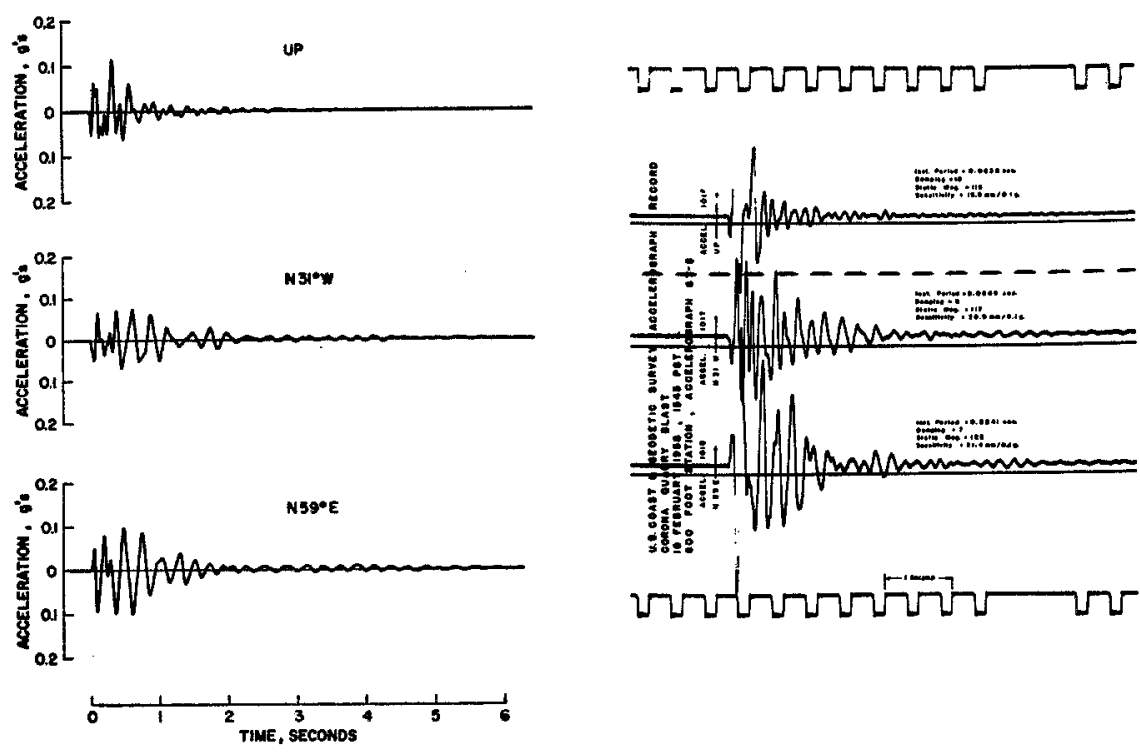

26 JULY 1952 - MLL BUILDING STATION

PHOTOGRAPH OF ORIGINAL ACCELERATION - TIME RECORO
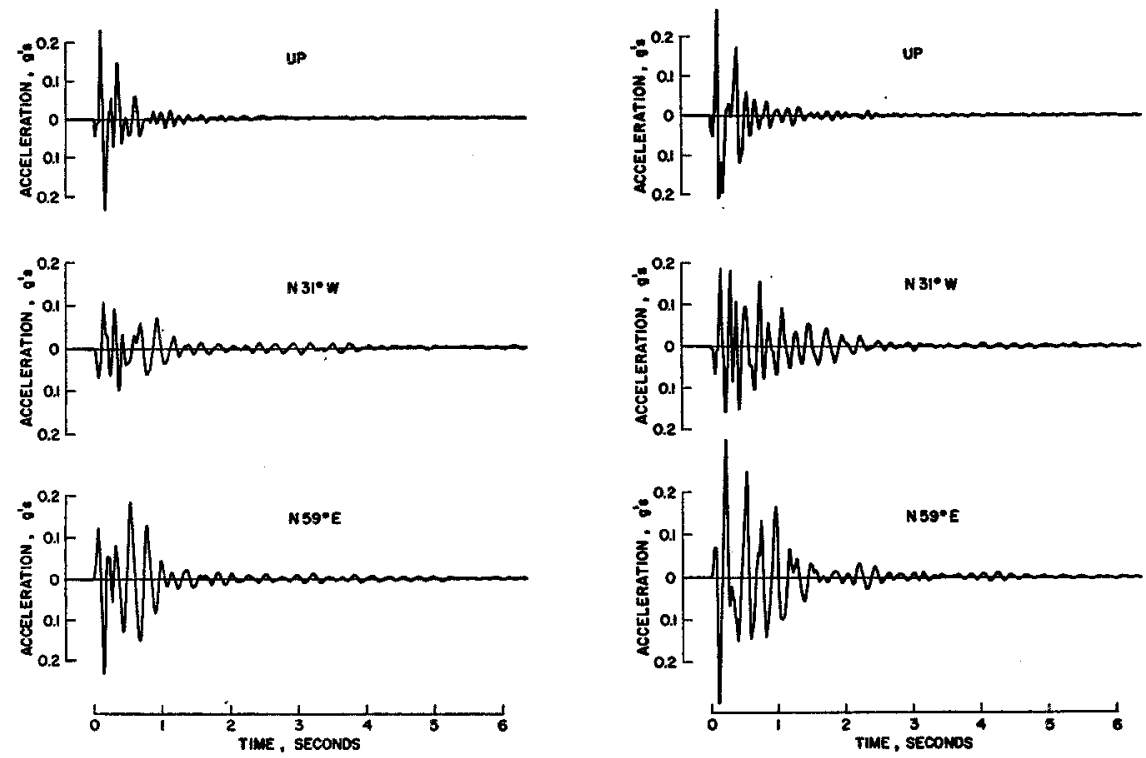

I8 FEBRUARY 1958 - MILL BUILDING STATION

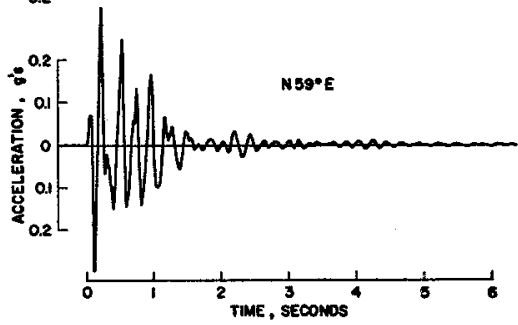

18 FEERUARY 1958 - 800 FOOT STATION

Frg. 2. Ground Acceleration-Time Records for Corona Blasts of 1952 and 1958. 


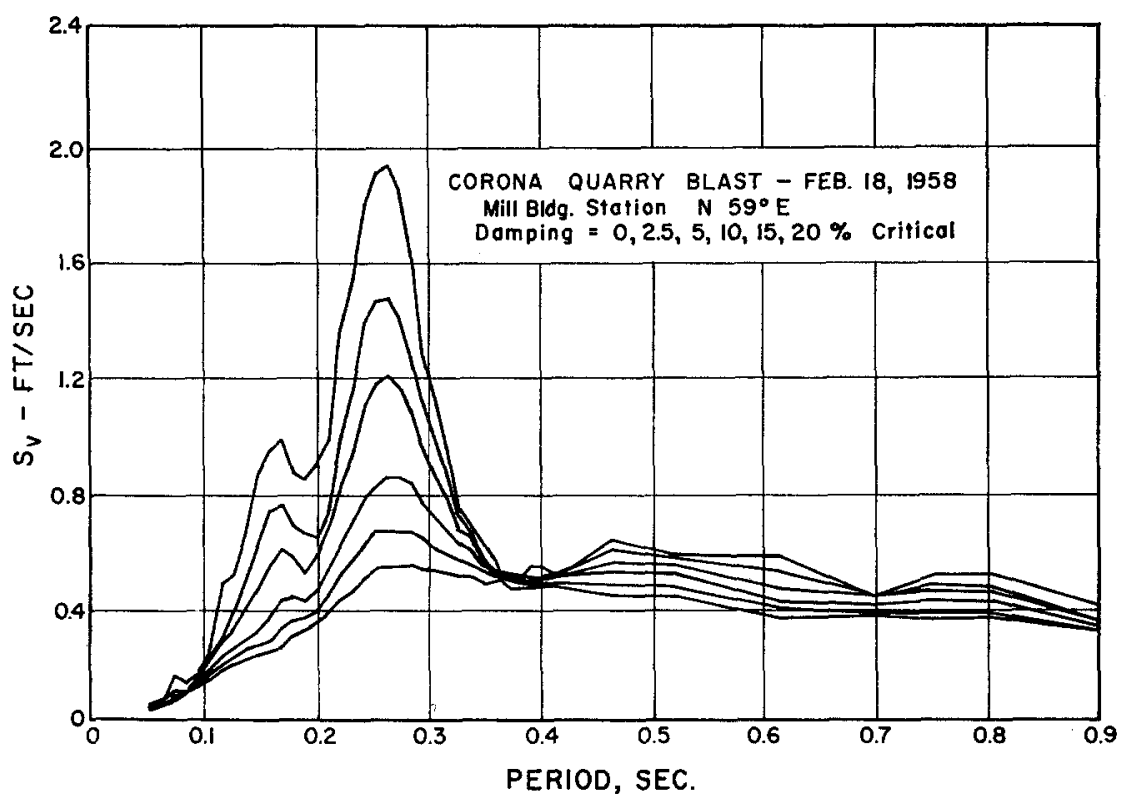

Frg. 3. Response Spectrum for 1958 Corona Blast, Mill Building Station, N $59^{\circ} \mathrm{E}$.

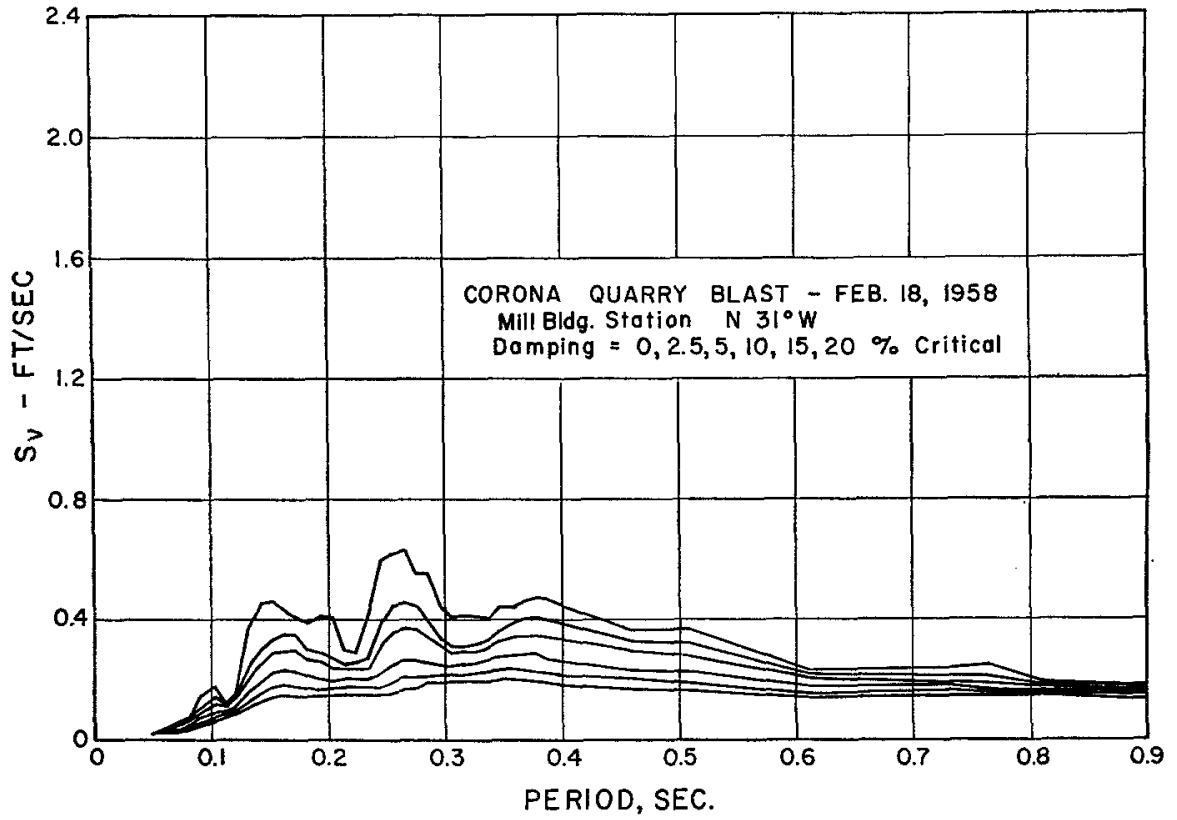

FIG. 4. Response Spectrum for 1958 Corona Blast, Mill Building Station, N $31^{\circ} \mathrm{W}$. 


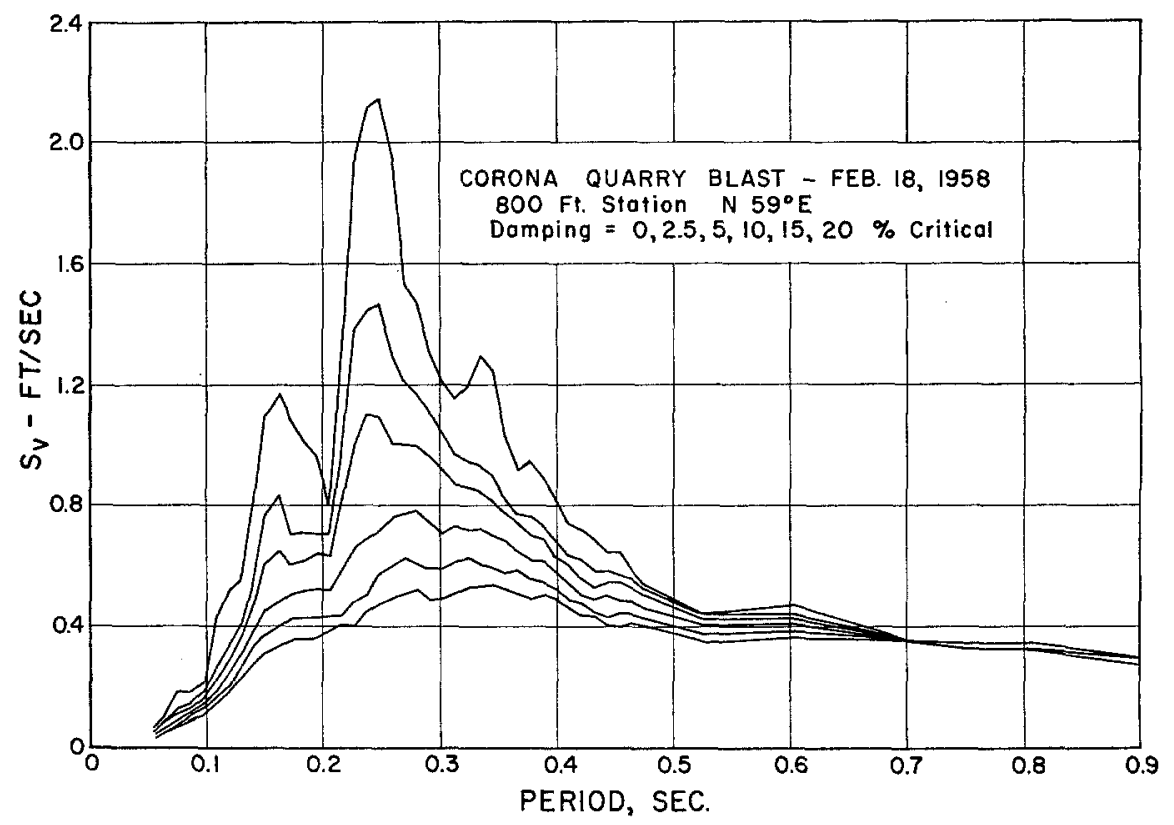

FIg. 5. Response Spectrum for 1958 Corona Blast, 800 Ft. Station, N $59^{\circ} \mathrm{E}$.

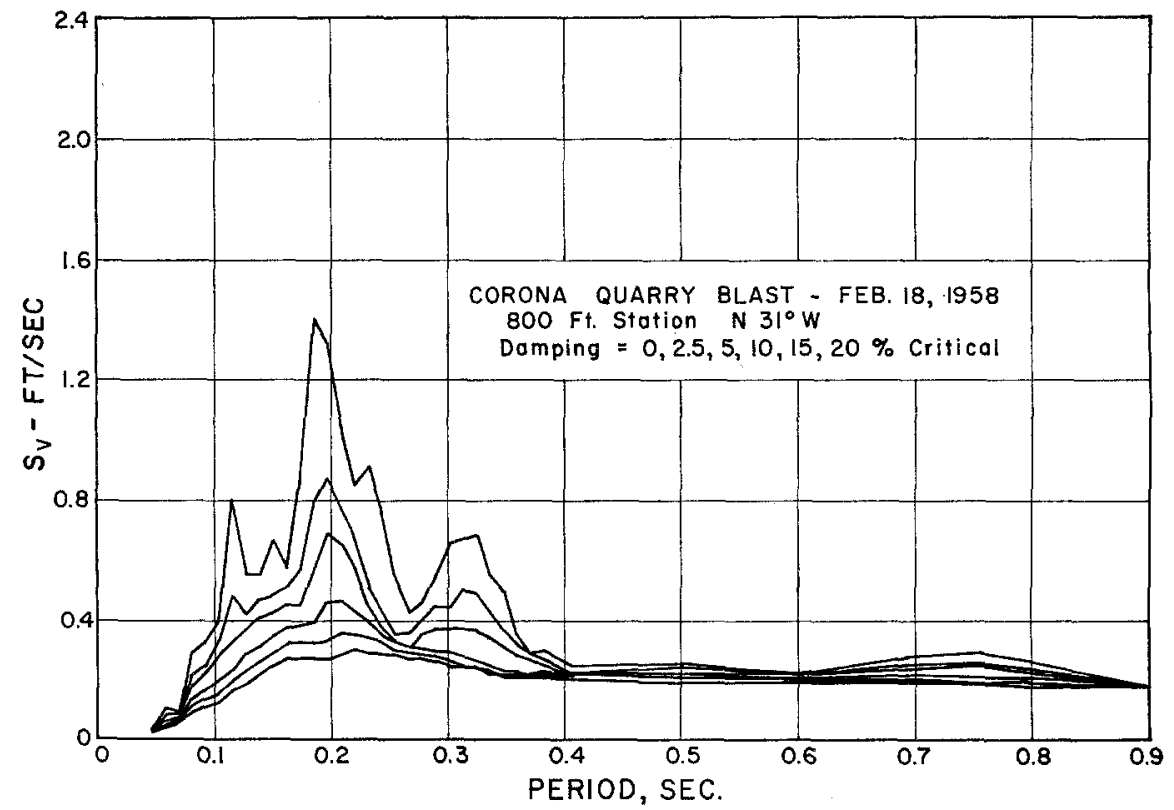

FIG. 6. Response Spectrum for 1958 Corona Blast, $800 \mathrm{Ft}$. Station, N $31^{\circ} \mathrm{W}$. 


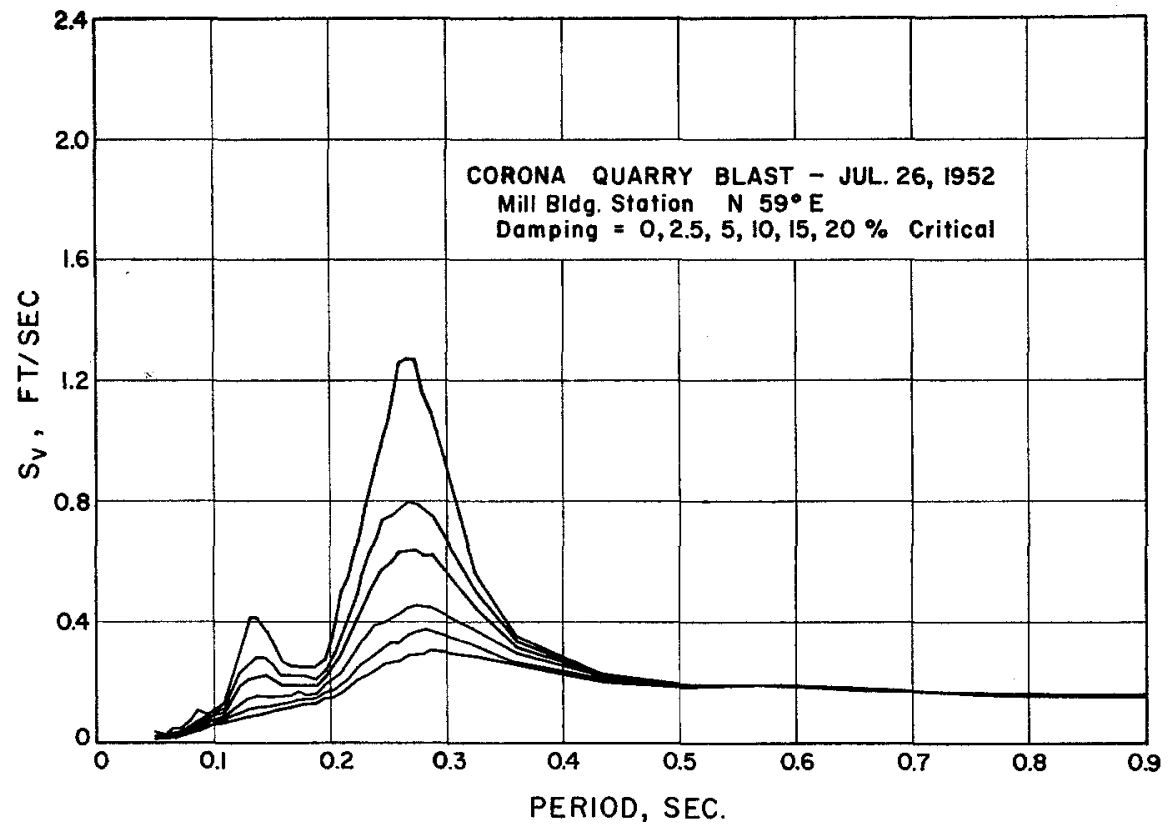

FIG. 7. Response Spectrum for 1952 Corona Blast, Mill Building Station, $\mathrm{N} 59^{\circ} \mathrm{E}$.

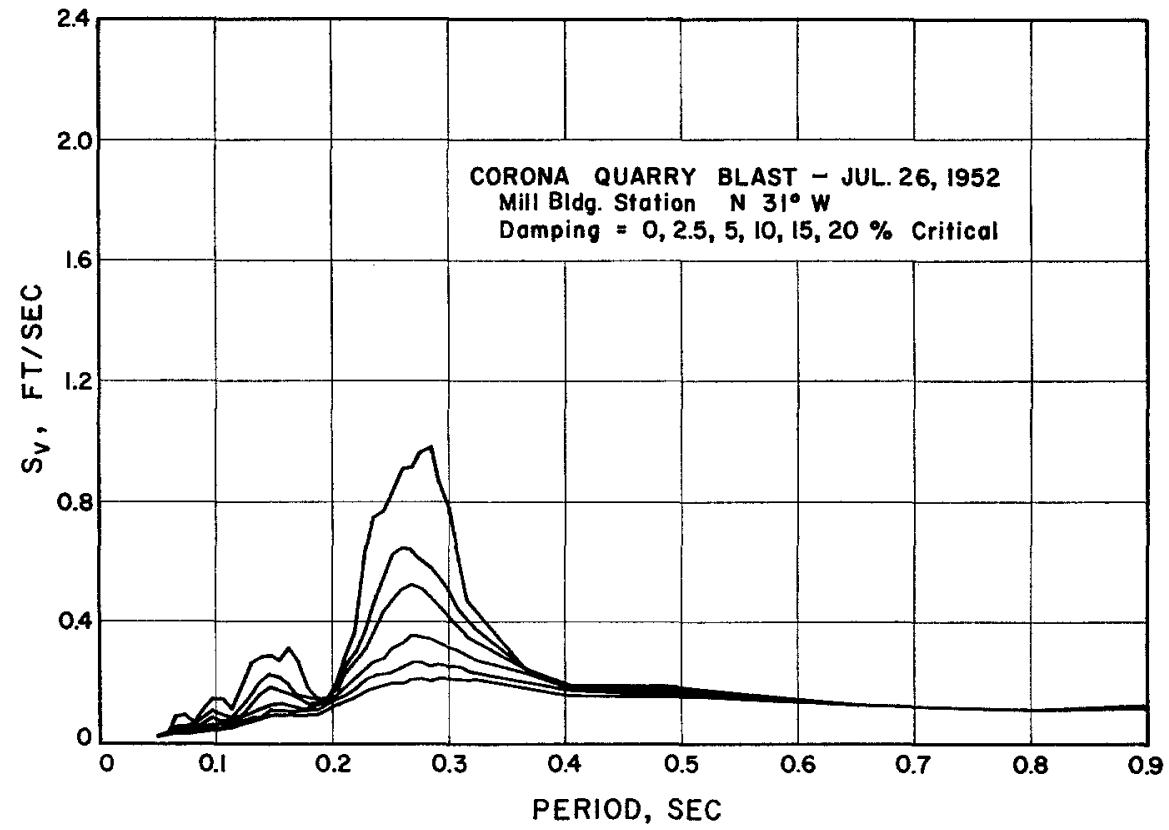

FIG. 8. Response Spectrum for 1952 Corona Blast, Mill Building Station, $\mathrm{N} 31^{\circ} \mathrm{W}$. 
spectrum shape, with one or two pronounced peaks, as would be expected from the relative simplicity of the propagation paths as compared with earthquakes.

\section{Peak Acceleration Magnitudes}

It is of interest to compare the ground acceleration magnitudes developed by the Corona blasts with similar measurements at other sites. For this purpose, other tests using the standard U.S.C.G.S. accelerographs are of most importance, since the results can be directly compared.

A glance at fig. 2 will quickly show that the present tests throw no light on the question of attenuation of acceleration with distance. In fact, the more distant station recorded definitely larger accelerations. The instrument located at a horizontal distance of $\mathbf{1 7 0 0} \mathrm{ft}$. from the center of the blast zone had a maximum peak horizontal acceleration of $0.30 \mathrm{~g}$, whereas the $1300 \mathrm{ft}$. instrument had a corresponding peak of $0.23 \mathrm{~g}$. The effects of local soil and sub-surface conditions have evidently overcome any small distance effect, which is not surprising in view of the small distance difference in the stations. An inverse square acceleration-distance relationship would suggest a peak acceleration at the Mill Building of about 1.7 times that at the $800 \mathrm{ft}$. station, and it is well known that local geological conditions may influence the ground acceleration by a larger factor than this. These data do indicate in a very direct way, however, the difficulties of attempts to generalize such blast data.

A comparison of the 1952 and the 1958 blasts from the standpoint of the acceleration-charge weight relationship involves an uncertainty as to the effects of the time delays used in the 1958 blast. Using the maximum simultaneous charge of 376 tons as compared with the 185 tons of the 1952 shot, the exponent of the accelerationcharge weight relationship would be 1.18 . Using the total charge of 673 tons, the exponent would be 0.645 . These figures may be compared with the value 0.75 which has been taken as an average for certain studies of the United States Coast and Geodetic Survey. ${ }^{6}$ The conclusions of these U.S.C.G.S. studies, which were made in preparation for the Rainier nuclear shot, can be summarized in the expression:

$$
\text { maximum ground acceleration }=\frac{0.95(\text { charge weight, tons })^{0.75}}{(\text { distance }, \mathrm{ft} .)^{2}} \times 10^{4} \mathrm{~g} \text { 's. }
$$

This expression is plotted in fig. 9. These curves are based mainly on measurements made with 10-ton and 50-ton charges at distances of approximately $300 \mathrm{ft}$. in a volcanic tuff material. As shown by Carder and Cloud, ${ }^{6}$ the acceleration measurements made during the Rainier nuclear shot also followed the above relationship with reasonable accuracy over a wide distance range, when calculated as an equivalent charge weight of 1.7 kilotons. The agreement was in fact better than might have been expected in view of the fact that different fractions of the total energy of the charge would likely go into exciting ground motion for the different types of blast.

\footnotetext{
${ }^{6}$ Carder, D. S., and W. K. Cloud, "Surface Motions from Large Underground Explosions," Jour. Geo. Res., vol. 64, No. 10, October 1959.
} 
Also shown in fig. 9 are the acceleration values that would have been recorded at Corona if the same relationship had been followed as in the Rainier tests, together with the actual measured accelerations. On the same figure is given an additional comparison of data from a 125 ton shot at the United States Navy Proving Grounds at Arco, Idaho. ${ }^{6}$ It will be seen that the agreement between the plotted relationship and the Corona tests is in general of the same order of magnitude as the agreement

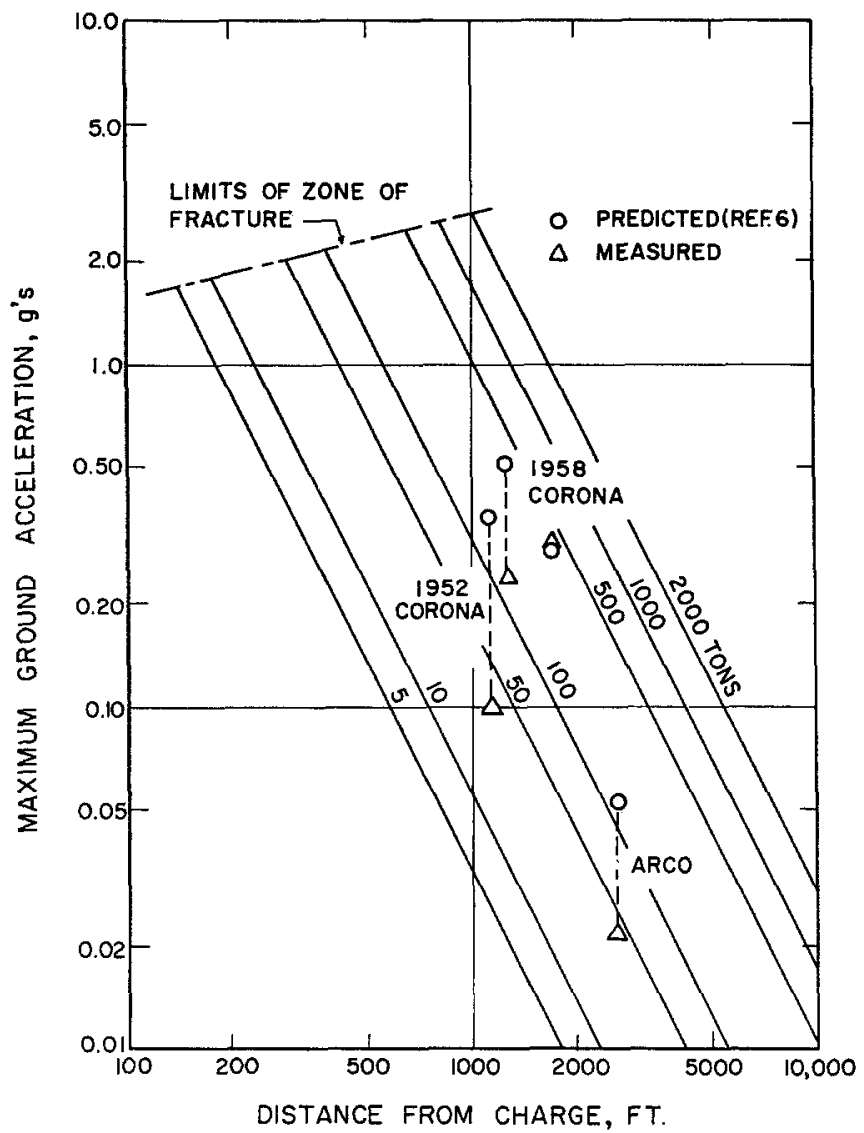

Frg. 9. Ground Acceleration-Distance-Charge Weight Relationships for Large Blasts.

with the Arco test. It is of interest to note that all of the above large blasts, taking place under widely differing conditions, give ground acceleration relationships agreeing within roughly a two-to-one level of approximation.

Included in the reports of Carder and Cloud ${ }^{6,7}$ are several velocity response spectrum curves calculated from ground accelerations measured during the Rainier nuclear shot. Those curves have been obtained in the same way as those presented in the present paper, and may be directly compared with them.

7 Carder, D. S., and W. K. Cloud, "Ground Motions Generated by Underground Nuclear Explosions," Proc. Second World Conference on Earthquake Engineering, Tokyo, 1960. 


\section{Ground Velocity Data}

A number of investigators have shown that there is a correlation between maximum ground velocity during a blast or earthquake and the general level of structural damage. For example, a series of blast damage tests made by Edwards and Northwood $^{8}$ showed that over a frequency range of 5 to 100 cycles per second, significant structural damage of typical small brick and timber houses began at peak ground velocities of 4 to 5 inches per second. Measurements made by other experimenters under differing conditions have given similar results..$^{9,10}$

The same conclusion has been reached by Neumann, ${ }^{11}$ who has investigated the relationship between Modified Mercalli intensities and ground motion. He has found that over the range of periods of structural interest, a given Modified Mercalli

TABLE II

Maximum Ground Velocities

\begin{tabular}{|c|c|}
\hline Blast & Max. Gd. Velocity, in./sec. \\
\hline \multicolumn{2}{|l|}{ July 26,1952} \\
\hline \multicolumn{2}{|l|}{ Mill Building } \\
\hline $\mathrm{N} 31^{\circ} \mathrm{W}$. & 1.3 \\
\hline $\mathrm{N} 59^{\circ} \mathrm{E}$ & 1.9 \\
\hline \multicolumn{2}{|l|}{ February 18,1958} \\
\hline \multicolumn{2}{|l|}{ Mill Building } \\
\hline $\mathrm{N} 31^{\circ} \mathrm{W}$ & 1.5 \\
\hline $\mathrm{N} 59^{\circ} \mathrm{E}$. & 4.5 \\
\hline \multicolumn{2}{|l|}{$800 \mathrm{Ft}$. Station } \\
\hline $\mathrm{N} 31^{\circ} \mathrm{W}$. & 2.3 \\
\hline $\mathrm{N} 59^{\circ} \mathrm{E}$ & 3.5 \\
\hline
\end{tabular}

intensity can be correlated with a constant maximum ground velocity, and on his suggested scale the 4 to $5 \mathrm{in}$./sec. range would correspond to a Modified Mercalli intensity of between VII and VIII. It thus appears that earthquakes and blasts have essentially the same fundamental character as far as certain types of structural damage are concerned.

The peak ground velocities for the Corona blasts can be easily determined from the velocity response spectrum curves. These velocity response spectrum curves give directly the maximum relative velocity between the structural mass and the ground. A relatively large period setting on the spectrum analyzer corresponds to a very flexible structure, and if this period is large compared to any prominent period components in the ground motion, the absolute motion of the structural

${ }^{8}$ Edwards, A. T., and T. D. Northwood, "Experimental Blasting Studies on Structures," the Hydro-Electric Power Commission and the National Research Council, Canada, 1959.

${ }^{9}$ Crandell, F. J., "Ground Vibration Due to Blasting and Its Effect Upon Structures," Jour. Boston Soc. Civ. Eng., vol. 36, No. 2, April 1949.

10 Langefors, V., H. Westerberg, and B. Kihlström, "Ground Vibrations in Blasting," Water Power, vol. 10, No. 9, 10, 11, Sept.-Nov. 1958.

11 Neumann, F., "Seismological Aspects of the Earthquake Engineering Problem," Proc. Third N.W. Conf. of Struct. Eng., Inst. of Tech., State College of Washington, Mar. 16, 17, 1959. 
mass would be small. Under these conditions the relative velocities would be approximately equal to the ground velocities themselves. It will be observed from the spectrum curves of figs. 3-8 that all of the curves become roughly constant after the $0.8-0.9$ second period range, and this constant velocity would therefore be a close approximation to the maximum ground velocity. These ground velocities have been tabulated in Table II.

No significant structural damage occurred to any of the buildings at the site during either blast. A description of the structural aspects of the main Mill Building is given in a previous publication covering building vibration measurements made during the July 26, 1952 blast. ${ }^{12}$ This building had been specially designed to withstand dynamic forces caused by installed mill machinery, and hence has a higher lateral force resistance than many structures of the same general character. The other buildings at the site were small, well designed and constructed structures, of higher than average resistance to lateral forces.

The ground velocity values of Table II are seen to be consistent with the observed absence of structural damage, and the data of the other investigators mentioned above. While the negative nature of the conclusion does not permit any quantitative check on the damage velocity criterion, it is of interest to note that so far there does not seem to be any basically different damage mechanism between earthquakes and blasts. In this sense, a blast can evidently be considered as a small, short duration earthquake, with somewhat narrower distribution of important period components than a typical destructive earthquake.

\section{Conclusions}

The most important data for the study of the effects of blasts and earthquakes on structures are true ground acceleration-time records, as obtained with a highfrequency response accelerograph. With such a record as the starting point, all of the significant ground motion parameters can be calculated. As a means of comparing various blasts, and of comparing blasts with earthquakes, it is important that a body of such ground acceleration data be built up. ${ }^{13}$

The results of the response spectrum calculations made for the two Corona blasts suggest that there are many similarities between earthquakes and blasts. It should be possible to make use of some of these similarities to estimate the damaging potential of future blasts. It should also be possible to use controlled blasts as a means of generating artificial test earthquakes, for structural damage studies.

The present tests, in connection with previous studies, indicate that while important effects of local geological conditions may exist, it should be possible to estimate for large blasts the maximum ground acceleration to within a factor of two or three, even for widely differing conditions. This order of accuracy may be sufficient to arrive at useful conclusions concerning the structural damage aspects of the problem.

12 Hudson, D. E., and G. W. Housner, "Structural Vibrations Produced by Ground Motion," Trans. A.S.C.E., vol. 122 , p. $705,1957$.

${ }_{13}$ Alford, Jack L., "Damage Produced by Small Ground Motions," Proc. Second World Conference on Earthquake Engineering, Tokyo, 1960. 


\section{ACKNOWLEDGMENTS}

We are grateful to the Minnesota Mining and Manufacturing Company for their interest and cooperation which made these tests possible. Mr. R. E. Gundlach, regional manager, and Mr. G. J. LaVenture, production superintendent of the Corona quarry were most helpful throughout the project. Thanks are due Mr. W. K. Cloud and the United States Coast and Geodetic Survey for their cooperation, and to Mr. Jerry Morrill and Mr. Richard Maley of the U.S.C.G.S. for their assistance with the instrumentation. We should also like to express our appreciation to the National Science Foundation for their support through a research grant administered by their Engineering Sciences Division, which has contributed to the analysis of the data reported above.

D.E.H. AND W.D.I, Division of Enginetring, California Institute of Technology, Pasadena, California.
J.L.A., Department of Engineering, Harvey Mudd College, Claremont, California. 